\title{
食品用粘度調整剂と嚥下補助斉の薬物動態への影響
}

\author{
森田俊博 ${ }^{* 1}$, 高根 浩 $^{2}$, 大坪健司 ${ }^{2}$, 家入一郎 ${ }^{3}$ \\ 済生会境港総合病院薬斉科 ${ }^{1}$, 鳥取大学医学部附属病院薬斉部 ${ }^{2}$, \\ 九州大学大学院薬学研究院薬物動態学分野 ${ }^{3}$
}

\section{Effect of Food Thickener and Deglutition Aid Jelly on Pharmacokinetics of Drugs}

\author{
Toshihiro Morita*1, Hiroshi Takane ${ }^{2}$, Kenji Otsubo ${ }^{2}$ and Ichiro Ieiri ${ }^{3}$ \\ Department of Pharmacy, Saiseikai Sakaiminato General Hospital ${ }^{1}$, \\ Department of Pharmacy, Tottori University Hospital ${ }^{2}$, \\ Department of Clinical Pharmacokinetics, Graduate School of Pharmaceutical Sciences, \\ Kyushu University ${ }^{3}$
}

\author{
$\left[\begin{array}{l}\text { Received A ugust 11, } 2010 \\ \text { A ccepted October 29, } 2010\end{array}\right]$
}

Some food thickeners and deglutition aid jellies have been reported to be associated with drug-food interactions because they contain a lot of saccharides and dietary fiber.

A cetaminophen was used as a model drug and administered to healthy volunteers as one of 3 forms ". drug alone" , " THICKENER" (mixed with 4\% solution of a commercially available food thickener) and" JELLY" (mixed with commercially available deglutition aid jelly). We then monitored their acetaminophen plasma levels. There were no significant differences in acetaminophen levels between the drug alone and JELLY forms, whereas the THICKENER form brought about a significant increase in $T \max (0.75$ to $1.5 \mathrm{hr}$ ).

Next, we tested the effect of the JELLY form on the plasma levels of 3 other drugs (sodium valproate, carbamazepine, and theophylline) in patients and observed comparable plasma concentration-time curves for all of them.

Finally, a dissolution test was performed to further evaluate the effect of the THICKENER form on drug plasma levels. As compared with the drug alone and the JELLY form, the THICKENER form significantly delayed dissolution for all drugs tested other than a theophylline sustained release preparation. We observed an increase in $\mathrm{T}_{80}$ (time for release of 80 $\%$ of the total content) for acetaminophen from 2.5 to $25.5 \mathrm{~min}$, in $\mathrm{T}_{85}$ for valproate from 9.8 to $42.8 \mathrm{~min}$, and in $\mathrm{T}_{75}$ for carbamazepine from 12.0 to $33.8 \mathrm{~min}$.

These results suggest that commercially available food thickeners are likely to be associated with changes in the pharma cokinetic profiles of clinically important drugs, and they therefore need to be carefully used in certain clinical situations.

Key words — dy sphagia, deglutition aid jelly, thickener for food, pharmacokinetics, drug-food interaction

\section{緒言}

近年, 生活習慣の多樣化や ADL(activities of daily living)低下患者への対応を目的にバリアフリー製剂の開発 が盛んになっている ${ }^{12)}$. 例えば，水なしで服用可能な口 腔内速崩壊錠 ${ }^{3,4}$, ゼリ一製剂等の新剂形が数多く開発さ れるようになった および普及率は未だ低く，すべての内用薬処方を新剂形 のみに置き換えることは出来ない，弚のため, ADLの 程度によっては指示通りの使用ができないばかりか, 誤 嚥性肺炎や薬斉性潰瘍等，医薬品自体が疾患の原因とな
るケースが多数報告されている6-15) .このような背景の 中, 医薬品の服用性を改善し, 患者のQOL(quality of life)を上げる目的で, 嚥下障害者の攝食介助用卜ロミ調 整剂(食品用粘度調整剂)が多くの介護施設や医療機関で 利用されている6 ${ }^{6,16-19)}$. また, 最近は服薬専用に開発さ れた服薬補助ゼリーも市販されるようになった .これら の製品の普及により嚥下障害者の服薬が容易になり，服 薬アドヒアランスも改善されてきた ${ }^{616-19)}$. しかし , こ れらの製品の多くは糖類(炭水化物)や食物繊維を多く含 むため, 薬物の吸着や吸収阻害等の可能性が否定できな い. 例えば , 糖分を多く含む食品がアセトアミノフェン の消化管吸収を遅延させる20)ことや食物繊維を多く含む

\section{鳥取県境港市米川町 44 番地}


医療薬学 Jpn. J. Pharm. Health Care Sci.

食品が三環系抗うつ薬を吸着し，血中濃度を低下させ る2122)ことが知られている．また，トロミ調整剂等の高 分子マトリクスは混和された薬物のマトリクスからの溶 出速度を低下させるという報告もあるため ${ }^{23-27)}$, 上部消 化管における吸収過程への影響も懸念される .

しかし，臨床においてトロミ調整剂または服薬補助剤 と患者が服用中の処方薬物との相互作用ならびに影響の 程度について比較・検討した例はない。

今回，われわれは服薬補助ゼリーやトロミ調整阂等の 服薬補助剂の薬物血中濃度への影響を評価するために， 市販の服薬補助ゼリーの一つまたは市販のトロミ調整剂 の一つで調製したトロミ調整剤水溶液にアセトアミノ フェンを混和後, 健常成人ボランティアに投与し, 薬物 単独投与の時の薬物血中濃度と比較・検討した . また, 相互作用のメカニズムの一つとして考えられる高分子マ トリクスからの薬物の溶出について評価する目的で, 溶 出試験を行って，混和物からの薬物の溶出挙動を観察 し，前述のボランティア・スタディーにおける薬物血中 濃度との関連性評価を試みた .さらに，実際の患者にお ける処方薬の薬物動態への影響を確認する目的で, 厳密 な血中濃度の管理が必要な2829 バルプロ酸ナトリウム (VPA)，カルバマゼピン(CBZ)，テオフィリン(THEO)の 3 種類の TDM 対象医薬品の血中濃度への服薬補助ゼ リーの影響を入院中のボランティア患者において評価し た。

\section{方法}

\section{1. 試料}

服薬補助剂として使用した試料のうち，嚥下補助剤は ローカストビーンガム, キサンタンガム等の増粘多糖類 を主原料とする市販の服薬補助ゼリー1種類を兴のまま で, 食品用粘度調整剂はデキストリン，増粘多糖類を主 原料とする市販のトロミ調整剂 1 種類を製品の使用説明 書を参考にして, 服薬介助に利用されている濃度 $(2,4$ ， $6 \mathrm{w} / \mathrm{v} \%)$ の水溶液を調製して用いた . 投与医薬品として 使用した試料のうち，アセトアミノフェンはピリナジ ン央末(長生堂製薬(株))を，VPA はデパケン ${ }^{\circledR}$ 細粒 $40 \%$ ((株)協和醴酵キリン)を，CBZ はテグレトール細粒 50 $\%\left(\right.$ ノバルティス(株))を，THEO はテオドール ${ }^{\circledR} \mathrm{G}$ 顆粒 20 $\%($ (株)田辺三菱製薬)を用いた .

\section{2. 物性評価}

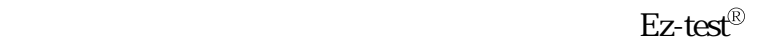
よび専用データ処理ソフト $\mathrm{SHiKiBu}^{\circledR}($ (株)島津製作所)を 使用した . 測定は咀嚼動作により口腔内で食物が崩れ， 再凝集する現象を再現し，歯や顎の代わりに圧縮治具に かかる荷重を測定することにより食品の食感や飲み込み やすさに関わる物性を算出することができる咀嚼試験 モードにて行った ${ }^{17}$ (http : //www.shimazu.co.jp/test/ , 島 津製作所カスタマーサポートセンター, オートグラフカ
スタム製品情報N o.22 - 食品のテクスチャー測定 - 参 照) . 温度 $20 \pm 2^{\circ} \mathrm{C}$ で, 試料を内径 $40 \mathrm{~mm}$, 高さ $15 \mathrm{~mm}$ のシャーレに充填し，直径 $20 \mathrm{~mm}$ の円盤状圧縮治具を 速度 $300 \mathrm{~mm} / \mathrm{min}$. で繰り返し上下させ , 高さの $40 \%$ を圧縮して荷重を測定し，硬さ，凝集性，粘着性および 弾力性を求めた .なお, 測定は各ロット 6 回ずつ行い, その平均値を実測値とした。

3. アセトアミノフェンの体内動態への服薬補助ゼリー およびトロミ調整剤添加の影響

21〜40歳の健常成人ボランティア 10 名(男性 5 名， 女性 5 名)にアセトアミノフェン末 $0.5 \mathrm{~g}$ を単独，卜ロミ 調整剂 $4 \%$ 水溶液との混和物または服薬補助ゼリーとの 混和物の三形態で投与し，一定時間ごとに採血し，アセ トアミノフェン血中濃度を測定した . また，3つの投与 形態光れ光れにおけるアセトアミノフェン血中濃度から 薬物動態パラメータ(AUC, ke, Cmax, Tmax)を求め, トロミ調整剂水溶液や服薬補助ゼリー添加の影響を評価 した .

試験薬の投与は, 2 群 3 期のクロスオーバー法により アセトアミノフェン散単独, アセトアミノフェン散と服 薬補助ゼリー $10 \mathrm{~g}$ あるいは卜ロミ調整剂 $4 \%$ 水溶液 10 g との混和物を弚れ単回投与した .なお, 薬阂単独 の場合は水 $150 \mathrm{~mL}$ で, 混和物の場合は水なしで投与し た、また，アセトアミノフェン散と服薬補助ゼリーある いはトロミ調整剂 $4 \%$ 水溶液との混和は同一の試験担当 薬剂師がビーカー中でガラス棒を用い, 50 回練合して 行い, 混和後, 15 分以内に試験に供した . 採血および 薬物血中濃度測定は, 服薬後, $0,0.25,0.5,1,1.5,2$, 3，4，6，12，24 時間の計 11点で採血を行い, アセ卜 アミノフェン血中濃度を蛍光偏光免疫測定法(FPIA 法, $\mathrm{TDx}^{\circledR}$; ダイナボット(株))により測定した .なお，アセ トアミノフェン体内動態への影響を評価するために， モーメント解析により動態パラメータを求めた . また, 有意差の検定は, ANOVA 解析により行った .

\section{4. 服薬補助ゼリーおよびトロミ調整斉の薬物溶出への 影響}

服薬補助ゼリーやトロミ調整剤が薬物動態パラメータ に影響を与える要因として，混和された薬物のゲルマト リクスからの溶出抑制や原料成分への吸着による吸収抑 制が考えられる．今回，ゲルマトリクスからの溶出抑制 に注目し，モデル薬物と服薬補助ゼリー $4 \mathrm{~g}$ あるいは卜 口ミ調整剂 2, 4, 6\% 水溶液 $4 \mathrm{~g}$ との混和物からのモデ ル薬物の溶出挙動を基に，影響の評価を試みた。なお， モデル薬物にはピリナジン ${ }^{\circledR}$ 末(アセトアミノフェン) $0.2 \mathrm{~g}$, デパケン ${ }^{\circledR}$ 細粒 $40 \%$ (VPA $) 0.5 \mathrm{~g}$, テグレトール ${ }^{\circledR}$ 細 粒 $50 \%$ (CBZ)0.4g , テオドール ${ }^{\circledR} G$ 顆粒 $20 \%$ (THEO) $1 \mathrm{~g}$ を用いた。 
1)溶出試験

モデル薬物とゼリーとの混和は同一の試験担当薬剤師 がビーカー中でガラス棒を用い，50回練合して行い， 混和後, 15 分以内に試験に供した。溶出試験は, JPXV 溶出試験法第 2 法(パドル法)に準じ，溶出試験器(NTR6000 : 富山産業(株))を用いて行った。また，試験液，パ ドル回転数および薬物定量法は日本薬局方外医薬品規格 第三部(局外規)に従った . 試験液はアセトアミノフェ ン,VPA，CBZ にはJPXV 崩壊試験法第一液( $\mathrm{pH}$ 1.2)を， THEO は徐放性製剂であり，第一液にはほとんど溶出し ないため，JPXV 崩壊試験法第二液(pH 6.8)を用いた。な お, 試験液量 $900 \mathrm{~mL}$ と液温 $37 \pm 0.5^{\circ} \mathrm{C}$ は共通である. パドル回転数は，アセトアミノフェン，VPA，THEO で は $50 \mathrm{rpm}, \mathrm{CBZ}$ では $75 \mathrm{rpm}$ とした . 試験液は試験開始 後 $1,2,4,6,10,15,30,45,60,90,120$ 分の 各 時間ごとにピペットマンにて $5 \mathrm{~mL}$ ずつ採取した . 採取 後はただちに同温同量の試験液を補充した . 採取した試 験液を $0.45 \mathrm{~m}$ mのメンブランフィルターでろ過後, 弚れ ぞれの薬物の定量法に従って薬物濃度を測定し, 溶出率 を求めた .

各試料 6サンプルずつの溶出試験を行い，局外規でモ デル薬物製剂ごとに規定されている溶出規格(規定溶出 率への到達時間)を溶出曲線から求めた .

2)モデル薬物定量法

(1)アセトアミノフェン(HPLC 法)

HPLC システムは LP-VP システム(株)島津製作所)を 用いた . カラムは逆相シリカ系(YMC-Pack ODSA A$302: \varphi 4.6 \mathrm{~mm} \times 15 \mathrm{~cm}$, $5 \mu \mathrm{m}$ : (株)ワイエムシイ)を使用 し , カラムオーブン温度は $30^{\circ} \mathrm{C}$ とした . 移動相には $0.05 \mathrm{M}$ リン酸二カリウム溶液 $(\mathrm{pH}$ 4.7)/メタノール混液 (4: 1)を用い，流速は $0.8 \mathrm{~mL} / \mathrm{min}$ ．とした．溶出液のろ 液 $1 \mathrm{~mL}$ に内部標準溶液(テオフィリン $5 \mathrm{\mu g} / \mathrm{mL}$ ) $1 \mathrm{~mL}$ を 加え, 兴の内 $2 q \mathrm{~L}$ を HPLC システムに注入した . 検出 波長は $244 \mathrm{~nm}$ の紫外吸光光度法にて行った .

(2) VPA (HPLC 法)

HPLC システムは LP-VPシステムを用いた . カラム は逆相シリカ系(Shim-Pack VP-ODS : $\varphi 4.6 \mathrm{~mm} \times 15$ $\mathrm{cm}, 5 \mathrm{\mu} \mathrm{m}$ : (株)島津製作所)を使用し, カラムオーブン 温度は $25^{\circ} \mathrm{C}$ とした . 移動相には $0.05 \mathrm{M}$ リン酸二水素ナ トリウム溶液 $(\mathrm{pH}$ 3.0)/アセトニトリル混液(1：1)を用 い, 流速は $1.0 \mathrm{~mL} / \mathrm{min}$.とした . 溶出液のろ液 $1 \mathrm{~mL} に$ 水 $1 \mathrm{~mL}$ を加え，弚の内 $5 q \mathrm{~L}$ を HPLC システムに注入 した. 検出波長は $210 \mathrm{~nm}$ の紫外吸光光度法にて行っ た。

(3) CBZ(紫外可視吸光度測定法)

紫外可視分光光度計は日立 U-3200(株)日立製作所)を 用いた，溶出液のろ液 $2 \mathrm{~mL}$ を正確に量り，水を加えて 正確に $50 \mathrm{~mL}$ とし測定用試料とした.水を対照とし ,285 $\mathrm{nm}$ における吸光度を測定した。

(4)THEO(紫外可視吸光度測定法)
紫外可視分光光度計は日立U-3200を用いた . 溶出液 のろ液 $1 \mathrm{~mL}$ を正確に量り，水で2倍希釈したJPXV 崩 壊試験法第二液(pH 6.8)を加えて正確に $20 \mathrm{~mL}$ とし測定

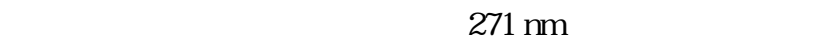
を測定した。

5. 入院患者における内服薬の体内動態への服薬補助ゼ リー添加の影響

健常成人ボランティアにおけるアセトアミノフェンの 体内動態に関する試験ならびにアセトアミノフェンの溶 出試験で添加による影響を示さなかった服薬補助ゼリー が, 血中濃度管理が重要なTDM 対象薬物においても影 響を示さないことを確認するために，TDM 対象薬物を 服用中の患者に服薬補助ゼリーを使用して服薬してもら い, 薬物単独のときの血中濃度と比較することにより，

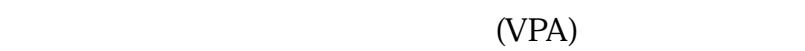
ン(CBZ)およびテオフィリン(THEO)を服用中で，日常的 にTDM を行っている入院患者から参加希望者を募った ところ，バルプロ酸 1 日 2 回 12 時間ごとの服用患者 5 名(男性 1名, 女性 4名; 40〜87 歳), カルバマゼピン 1 日 2 回 12 時間ごとの服用患者 5 名(男性 5名; 40〜83 歳), テオフィリン 1 日 2 回 12 時間ごとの服用患者 7 名 (男性 1名，女性 6名; 10〜87歳)が参加を希望した。

被験者が治療のために服用している薬物単独または服 薬補助ゼリーと混和した薬物のどちらか一方を 4 日間連 続して服用させ，服用開始から 4 5日目にバルプロ 酸, カルバマゼピンでは朝服用後 $0,6,12,16,24$ 時 間後，テオフィリンでは朝服用後 $0,6,12,16,24$ 時 間後の計 5 点, 弚れ艺れ約 $1 \mathrm{~mL}$ ずつ採血を行い, TDM 対象薬物の血中濃度を蛍光偏光免疫測定法(FPIA 法, $\left.T \mathrm{TDx}{ }^{\circledR}\right) に よ り$ 測定した．2週間後，残りの一方を服用さ せ，同樣な試験を実施した . 体内動態の評価は，モーメ ント解析により薬物動態パラメータを求めた .

なお, 本稿記載のすべての臨床試験は鳥取大学医学部 倫理委員会ならびに鳥取県済生会境港総合病院倫理委員 会の承認後, 実施した . また, 本稿には示さないが, 服 薬補助剂に関する詳細な説明書とプロトコールを作成 し，十分にインフォームド・コンセントを行って被験者 の文書同意を得た .

\section{結果と考察}

\section{1. 物性評価}

口に含んだ食品を飲み下すためには，口腔内で食品を 一塊にする必要がある．この塊になり易さを食塊形成性 といい，食品の凝集性に依存することが報告されてい $3^{29)}$. また, 飲み下す際の喉越しの良否には食品の変形 しやすさか関係しており，この性質は食品の硬さ，粘着 性および弾力性に依存することが報告されている ${ }^{30}$. 例 えば，硬くて変形しにくい焼いもは喉につかえるし，口 
医療薬学 Jpn. J. Pharm. Health Care Sci.

腔内に粘着するゆで卵の黄身も飲み込みづらいが, 弾力 性に富んだプリンやくず湯は嚥下機能の低下した高齡者 にも好評である .

服薬補助ゼリーや増粘剤が飲み下し易さを改善できる 理由は, 散剂や錠剂あるいは水剂の食塊形成性や変形し やすさを高めることによって口腔内での拡散や喉頭蓋谷 での滞留を防ぎ，飲み下す際(嚥下第 $I I$ 相)の食道通過性 (流動性)を改善するからであることが解明されている ${ }^{30}$ ため，これらの物性を評価することにより，易嚥下性の 改善効果が予測できると考えられる.

なお，市販の服薬補助ゼリーは产のままで，トロミ調 整斉水溶液は製品の使用説明書を参考にして，一般に服 薬介助に利用されている濃度 $(2,4,6 \mathrm{w} / \mathrm{v} \%)$ に調製し て物性を測定した。

服薬補助ゼリーの物性を測定した結果，硬さ(Hardness) が $287 \mathrm{~N} / \mathrm{m}^{2}$, 凝集性(Cohesiveness)が 0.92 , 粘着性(A dhe siveness)が - 1.75× 10-4 $\mathrm{N} / \mathrm{mm}$ ，弾力性(Springness)が 0.96 だった(Table 1)．今回，試験に供した市販の服薬補助ゼ リーは成人ボランティアおよび燕下障害患者における臨 床試験で散斉や水剂の飲み下し易さを改善することが確 認されている17ので，本服薬補助ゼリーはおおむね嚥下 し易い物質の物性を示していると考えられる．トロミ調 整剂水溶液の物性測定値はいずれも濃度に依存して増加 する傾向を示したが， $2 \%$ 水溶液では硬さが $94 \mathrm{~N} / \mathrm{m}^{2}$, 凝集性が 0.91 と服薬補助ゼリーに比して小さく，十分 な食塊形成性が得られない可能性が示唆された。また， $6 \%$ 水溶液では硬さは $250 \mathrm{~N} / \mathrm{m}^{2}$ と服薬補助ゼリーに近 かったが，粘着性が - 2.23× $10^{-4} \mathrm{~N} / \mathrm{mm}$ と大きく，口腔 内や喉頭粘膜への粘着により飲み下しにくくなる可能性 が示唆された .一方，4\% 水溶液では硬さは $169 \mathrm{~N} / \mathrm{m}^{2}$ と服薬補助ゼリーより小さいものの，凝集性が 0.93 と 服薬補助ゼリーと同程度だったため，以後のボランティ ア・スタディーで服薬補助ゼリーと比較する際には $4 \%$ 水溶液を適用することにした 。

2. アセトアミノフェンの体内動態への服薬補助ゼリー およびトロミ調整阂添加の影響

服薬補助ゼリーおよびトロミ調整剂 $4 \%$ 水溶液にアセ トアミノフェンを混和して服用した時のアセトアミノ
フェンの血中濃度 - 時間曲線をアセトアミノフェン単独 で服用した時の兰れと比較した。 弚の結果, 薬物単独群 (without jelly)と服薬補助ゼリー群(with deglutition aid jelly)がほぼ同樣の曲線を示したのに対し，トロミ調整 剂 4\% 水溶液群(with 4\% thickener)は血中濃度の立ち上 がりにラグタイムを生じ，最高血中濃度到達時間(T max) の遅延が認められた(Fig. 1) . 同樣に，モーメント解析 により求めた動態パラメータの比較においても, トロミ 調整剂 4\% 水溶液群(with 4\% thickener)の平均 T max 值は 薬物単独群(without jelly)の 0.75 時間に対し，1.50 時間 と有意に遅延していた(Table 2).

アセトアミノフェン薬物動態パラメータの比較から今 回，試験に供した服薬補助ゼリ一はアセトアミノフェン のように治療上, 血中濃度の立ち上がりが重要な薬物に 対して大きな影響を与えないことが確認できた .一方， 試験に供したトロミ調整剂 $4 \%$ 水溶液は薬物単独群 (without jelly)に比して有意にTmax が遅延したことか ら，治療効果への影響を考慮すると安易な使用は慎むべ きと考えられた。ただし，AUCへの影響は服薬補助ゼ

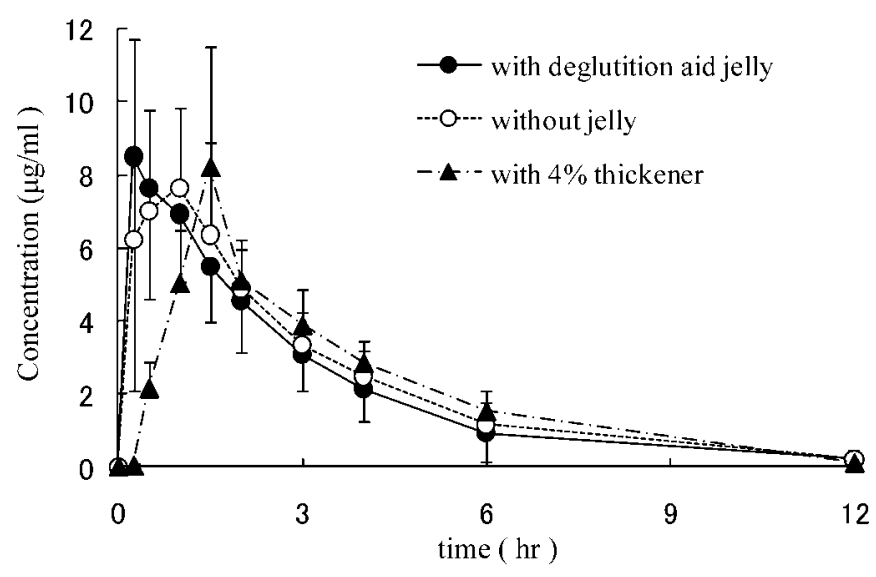

Fig 1. Plasma Concentration-Time Profile of Acetoaminophen

アセトアミノフェン単独で投与した場合と比 較して, 服薬補助ゼリーにアセトアミノフェ ンを混和または食品用増粘剂 $4 \%$ 水溶液にア セトアミノフェンを混和した時のアセトアミ ノフェン血中濃度推移がどのように変化する のかを示した .

Table 1 . Rheological properties of jelly

\begin{tabular}{ccccc}
\hline & $\begin{array}{c}\text { Hardness } \\
\left(\mathbf{N} / \mathbf{m}^{2}\right)\end{array}$ & Cohesiveness & $\begin{array}{c}\text { Adhesiveness } \\
(\mathbf{N} / \mathbf{m m})\end{array}$ & Springness \\
\hline deglutition aid jelly & 287 & 0.92 & $-1.75 \times 10^{-4}$ & 0.96 \\
$\mathbf{2 \%}$ thickener & 94 & 0.91 & $-0.31 \times 10^{-4}$ & 0.93 \\
$\mathbf{4 \%}$ thickener & 169 & 0.93 & $-0.90 \times 10^{-4}$ & 0.95 \\
$\mathbf{6 \%}$ thickener & 250 & 0.97 & $-2.23 \times 10^{-4}$ & 0.95 \\
\hline
\end{tabular}


Table 2 . Summary of pharmacokinetic paramters

\begin{tabular}{ccccc}
\hline & without jelly & $\begin{array}{c}\text { with deglutition } \\
\text { aid jelly }\end{array}$ & $\begin{array}{c}\text { with } \\
4 \% \text { thickener }\end{array}$ & $\begin{array}{c}\text { ANOVA } \\
P \text {-value }\end{array}$ \\
\hline $\begin{array}{c}\mathrm{AUC} \\
(\mu \mathrm{g} \cdot \mathrm{hr} / \mathrm{mL})\end{array}$ & $27.0 \pm 5.10$ & $25.3 \pm 7.43$ & $25.8 \pm 5.37$ & 0.808 \\
$\begin{array}{c}\mathrm{AUC} \mathrm{C}_{0-\infty} \\
(\mu \mathrm{g} \cdot \mathrm{hr} / \mathrm{mL})\end{array}$ & $27.7 \pm 5.55$ & $26.1 \pm 8.53$ & $26.1 \pm 5.58$ & 0.836 \\
$\mathrm{ke}(1 / \mathrm{hr})$ & $0.370 \pm 0.091$ & $0.402 \pm 0.161$ & $0.363 \pm 0.054$ & 0.698 \\
$\mathrm{C}_{\max }(\mu \mathrm{g} / \mathrm{mL})$ & $9.95 \pm 2.86$ & $11.2 \pm 3.28$ & $8.20 \pm 3.32$ & 0.130 \\
$\mathrm{~T}_{\text {max }}(\mathrm{hr})$ & $0.750 \pm 0.408$ & $0.525 \pm 0.343$ & $1.50 \pm 0.00^{*}$ & $<0.0001$ \\
\hline
\end{tabular}

* significantly different from without jelly $(P<0.0001)$ by Dunnett test with Bonferroni correction.

リー，トロミ調整㶡水溶液のいずれも大きくなかったこ とから，原料成分への吸着による吸収阻害はないか無視 できる程度であることが確認された 。

\section{3. 服薬補助ゼリーおよびトロミ調整斉の薬物溶出への 影響}

1)アセトアミノフェン溶出への影響

アセトアミノフェン散単独(without jelly)の $T_{80}$ は 2.5 分だった . 服薬補助ゼリーとの混和物(with jelly)の $T_{80}$ は 2.9 分でアセトアミノフェン散単独の場合と同程度 だった。一方, トロミ調整剤水溶液との混和物の $\mathrm{T}_{80}$ は $2 \%$ 水溶液(with $2 \%$ thickener)からでも 17.5 分かかり， 4 \%水溶液(with $4 \%$ thickener) では 25.5 分，6\% 水溶液(with $6 \%$ thickener)では 35 分だった. 後発医薬品で生物学的 同等性を評価する時に用いられる溶出規格は $T_{80}$ が 15 分以内となっているが, トロミ調整剂と混和した時はい ずれも規定時間を超過し，基準を満たすことが出来な かった .

\section{2)VPA 溶出への影響}

VPA 単独の $T_{85}$ は 9.8 分だった . 服薬補助ゼリーとの 混和物の $T_{85}$ は 12.5 分でVPA 単独の場合と同程度だっ た。しかし, トロミ調整阂水溶液との混和物の $T_{85}$ は 2 \%水溶液からでも 31.8 分かかり， $4 \%$ 水溶液では 42.8 分， $6 \%$ 水溶液では 60.8 分だった。 後発医薬品で生物学 的同等性を評価する時に用いられる溶出規格は $T_{85}$ が 15 分以内となっているが, トロミ調整剂と混和した時はい ずれも規定時間を超過し，基準を満たすことが出来な かった.

\section{3)CBZ 溶出への影響}

$C B Z$ 単独の $T_{75}$ は 12.0 分だった . 服薬補助ゼリーと の混和物の $T_{75}$ は 12.5 分で $C B Z$ 単独の場合と同程度 だった。しかし，トロミ調整斉水溶液との混和物の $T_{75}$ は $2 \%$ 水溶液からでも 26.3 分かかり，4\% 水溶液では 33.8 分, $6 \%$ 水溶液では 44.5 分だった. 後発医薬品で生 物学的同等性を評価する時に用いられる溶出規格は $\mathrm{T}_{75}$
が 30 分以内となっているが, トロミ調整剤と混和した 時は $4 \%$ 以上の水溶液濃度では規定時間を超過し，基準 を満たすことが出来なかった .

4)THEO 徐放性製剤溶出への影響

THEO は徐放性製剂であるため, 30 分の溶出率が 20〜50\%，60 分の溶出率が 40〜 70\% および 4 時間の溶 出率が $75 \%$ 以上となっているが, 30 分の溶出率は THEO 単独が $42.0 \%$, 服薬補助ゼリーとの混和物が 42.1 \% . 卜ロミ調整剂 2, 4, 6\% 水溶液との混和物が光れ光 れ 39.4, 35.6, 32.6\%，60 分の溶出率は THEO 単独, 服 薬補助ゼリーとの混和物およびトロミ調整剂 $2 \%$ 水溶液 との混和物がいずれも $59.0 \%$, 卜ロミ調整剂 4,6\% 水溶

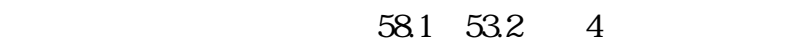
は THEO 単独および服薬補助ゼリーとの混和物が 94.0

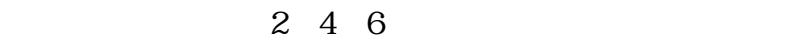
れ $94.1,94.1,94.0 \%$ でいずれも溶出規格範囲内に収まっ ており，徐放性製剂は他のモデル薬物と比べ影響が小さ かった(Fig. 2) .

上記の通り, トロミ調整剂との混和物からの薬物溶出 時間の遅延は過去の高分子マトリクスからの溶出制御に 関する報告 ${ }^{23-27}$ と同樣の傾向を示し，卜ロミ調整剂水溶 液の濃度が高くなるのに相関して遅延した . また, 試験 時間 120 分以上ではすべてのモデル薬物がモデル薬物単 独と服薬補助ゼリー混和物またはトロミ調整剂水溶液混 和物で同等の溶出率を示したことから，服薬補助ゼリー やトロミ調整阂の成分への吸着による影響はないと考え られた 。

\section{4. 入院患者における内服薬の体内動態への服薬補助ゼ リー添加の影響}

VPA，CBZ，THEO のいずれの薬物も薬物単独群 (without jelly)と服薬補助ゼリー混和群(with deglutition aid jelly)の間でAUC, MRT, トラフ濃度に差は認めら れなかった(Table 3) . この結果から，今回，試験に供し た服薬補助ゼリーは厳密な血中濃度管理が必要とされる 

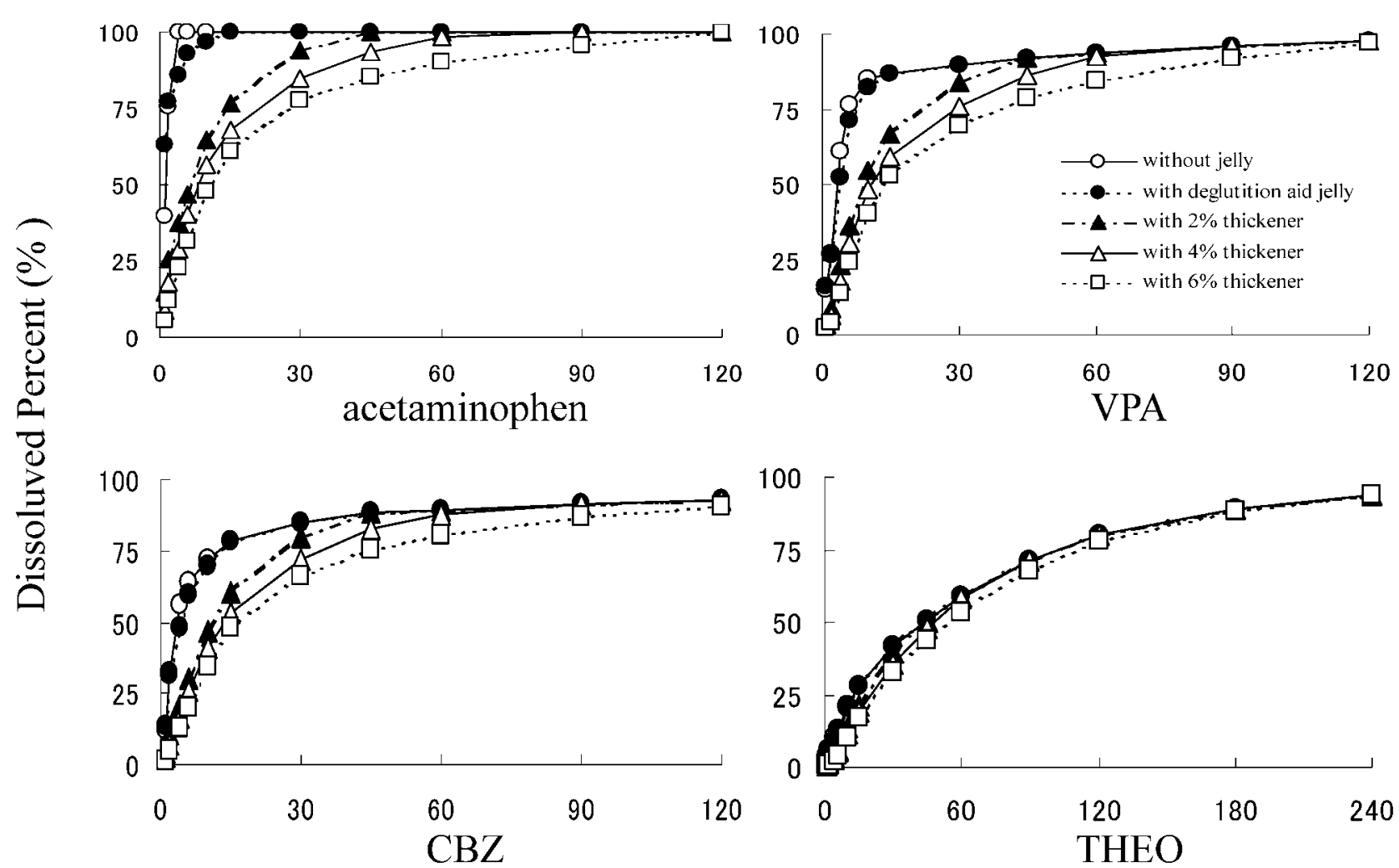

$$
\text { time ( min.) }
$$

Fig 2 . Effect o Concentration of Gel to Dissolution Profile of Drugs モデル薬物単独の場合と比較して, 服薬補助ゼリーにモデル薬物を混和または食品用増粘剂 $2,4,6 \%$ 水溶液にモデル薬物を混和したときのモデル薬物溶出挙動がどのように変化する のかを示した。

Table 3 . Effect of Jelly on The Pharmacokinetic Parameters

\begin{tabular}{|c|c|c|c|c|}
\hline & & $\mathbf{A U C}_{\mathbf{0}-\infty}$ & MRT & trough \\
\hline \multirow{2}{*}{ CBZ } & without jelly & 120.46 & 11.96 & 4.14 \\
\hline & with deglutition aid jelly & 118.74 & 11.85 & 4.06 \\
\hline \multirow{2}{*}{ THEO } & without jelly & 235.79 & 11.77 & 9.29 \\
\hline & with deglutition aid jelly & 235.67 & 11.77 & 9.07 \\
\hline \multirow{2}{*}{ VPA } & without jelly & 787.20 & 11.91 & 26.54 \\
\hline & with deglutition aid jelly & 776.76 & 11.94 & 25.70 \\
\hline
\end{tabular}

抗痙攣薬や気管支拡張斉の長期連用時においても，炎の 血中濃度推移に影響を与えないことが確認された 。

以上, 本研究において食品用粘度調整剂と嚥下補助剂 の内服薬の薬物動態への影響について検討した . 曼の結 果，ローカストビーンガム，キサンタンガム等の増粘多 糖類を主原料とする市販の服薬補助ゼリーは健常成人ボ ランティアにおけるアセトアミノフェンの体内動態およ び入院患者ボランティアにおける VPA，CBZ，THEO
の体内動態に影響を示さないことが確認された .一方， デキストリン, 増粘多糖類を主原料とする市販のトロミ 調整剤は通常の使用濃度である $4 \%$ 水溶液て健常成人ボ ランティアにおけるアセトアミノフェンの最高血中濃度 時間 Tmax を遅延させた . また, 兴の原因の一つはトロ ミ調整阂の高分子マトリクスに包含された薬物の溶出が 抑制され，アセトアミノフェンの吸收部位である上部消 化管での溶出が遅延したためであることが溶出試験結果 
から示唆された . 解熱鎮痛剂のように即効性を期待する 薬物でTmax が遅延することは臨床的に看過できない． 今後, 服薬介助にトロミ調整剂や服薬補助剂を利用する 際には, 易嚥下性の改善効果のみを基準にして安易に選 択するのは避け，薬物動態への影響が少ないことが確認 されている製品を選択する必要があると考えられる．

\section{引用文献}

1) 杉原正泰, 高齢者に適した剂形の開発と適用,月刊薬事， 38 , 35-38 (1996).

2) 山田安彦 , 伊賀立二 “高齢者における薬物療法の手引 き”厚生省・日本医師会編，じほう，東京，1995，pp.1435.

3) 高橋喜統, 西尾浩次, 西尾眞友, 嚥下障害を伴う患者の 問題点と服薬支援，月刊薬事，46，605-612 (2004).

4) 松里軒浩一, 山口正彦, 中田宏, 速崩壊錠に対する軽度 嚥下障害患者の評価, 医療薬学, 29,648-651 (2003).

5) 並木德之, 速崩壞錠の技術革新 ハイテク速崩壊錠, V alue added Genericsから院内製剂まで, 月刊薬事 , 47， 1969-1977 (2005).

6) 藤谷順子, 摂食・嚥下障害の看護と介護, 薬局, 51(5), 7-12 (2000).

7) 藤島一郎, 口から食べる - 嚥下障害 Q\&A, 中央法規 出版, 東京 1998 , pp.51-61.

8) 大谷壽一澤田康文 薬剂による食道潰瘍の実態と対策 , 薬局 , 51，1327-1332 (2000).

9) R. Ouatu-Lascar, G. Tiadafilopoulos, Oesophageal mucosal disease in elderly, Drugs and Aging, 12 , 261-276 (1998).

10) G. N. Zografos, D. Georgiadou, D. Thomas, G. Kaltsas, M. Digalakis, Drug-induced esophagitis, Diseases of the Esophagus , 22，633-637 (2009).

11) 木村健, 薬斉性食道潰瘍, 日本消化器病学会杂隹志, 75 , 64-70 (1978).

12) D. Jaspersen, Drug-induced oesophageal disorders: pathogenesis, incidence, prevention and management, Drug Saf., 22(3) , 237-249 (2000).

13）竹鼻敏孝, 右側大動脈弓による狭窄部に発生した薬斉性 食道潰痬の 1例，日本胸部外科学会杂隹誌，40，1131-1134 (1992).

14) M. S. Levine, Drug-induced disorders of the esophagus, $A b$ dom Imaging , 24 , 3-8 (1999).

15) J. A. Biller, Tetracycline induced esophagitis in adolescent patients, J. Pediatr, $120,144-145$ (1992).

16) 森田俊博, 服薬補助ゼリーの開発, 薬学杂倠誌, 123，665-
671 (2003).

17) 森田俊博, 嚥下補助食品の開発 -ペースト状のオブ ラートー，月刊薬事，46，673-682 (2004).

18) 大越ひろ, テクスチャー調整食品 一最近の傾向と使い 方のヒント - , 臨床栄養 , 51，178-185 (2004).

19) 大越ひろ, 増粘剂(卜ロミ調整剂)の適切な使用方法, Medical Rehabilitation, 57 , 132-139 (2005).

20) P. G. Welling, J. Pharmacokinet. Biopharm., 5 , 291-334 (1977).

21) D. E. Stewart, High-fiber diet and serum tricyclic antidepressant levels, J. Clin. Psychopharmacol., 12, 438-440 (1992).

22）渡邊真一，井上直人，今井公江，末丸克矢，荒木博陽， 相本太刀夫 , 医薬品と食物繊維との相互作用 - In V itro における医薬品の食物繊維への吸着一, 医療薬学 , 32, 221-226 (2006).

23) J. Liu, S. Lin, L. Li, E. Liu, Release of theophylline from polymer blend hydrogels, Int. J. Pharm., 298, 117-125 (2005).

24) S. Miyazaki, A. Takahashi, K. Itoh, M. Ishitani, M. Dairaku, M. Togashi, R. Mikami, D. A ttwood, Preparation and evaluation of gel formulations for oral sustained delivery to dysphagic patients, Drug Dev. Ind. Pharm., 35 , 780-787 (2009).

25) C. Sandolo, T. Coviello, P. Matricardi, F. Alhaique, Characterization of polysaccharide hydrogels for modified drug delivery, Eur. Biophys. J., 36 , 693-700 (2007).

26) A.A. Barba, M. d'A more, S. Cascon, S. Chirico, G. Lamberti, G. Titomanlio, On the behavior of HPMC/Theophylline matrices for controlled drug dlivery, J. Pharm. Sci., $98,4100-4110$ (2009).

27) C. Tapia, V. Ormazabal, E. Costa, M. Y azdani-Pedram, Study of dissolution behavior of matrices tablets based on alginate-gelatin mixtures as prolonged diltiazem hydrochloride release systems, Drug Dev. Ind. Pharm., 33 , 585-593 (2007).

28) I. Ieiri, K. Hirata, S. Higuchi, K. Kojima, M. Ikeda, H. Y amada, T. A oyama, Pharmacoepidemiological study on adverse reactions of antiepileptic drugs, Chem. Pharm. Bull ., 40, 1280-1288 (1992).

29) 山本康次郎““最新医療薬学 II”,伊賀立二, 乾賢一，澤 田康文編著，南山堂，東京，1999，pp.273-287.

30) 金谷節子, 新村広明, 橋爪さな枝, 吉村文枝, 嚥下障害 がある人が食べられる食事とは，臨床栄養，88，162167 (1996). 